Article

\title{
Overdose Deaths and Entrepreneurial Activity
}

\begin{abstract}
Albert Sumell
Department of Economics, Youngstown State University, Youngstown, OH 44555, USA; ajsumell@ysu.edu

Received: 1 October 2019; Accepted: 17 March 2020; Published: 23 March 2020

Abstract: Drug overdose deaths, primarily due to opioid addiction, have devastated communities in almost every area of the U.S. The economic impacts of the crisis include additional healthcare resources, unemployment, lost productivity, criminal justice costs, and other indirect impacts that have not yet been researched. This study aims to estimate one potential impact of opioid dependency in communities by estimating the relationship between drug overdose deaths and entrepreneurship. In particular, the empirical models measure how entrepreneurship, as measured by the percentage of self-employed workers, changes in relation to the number of overdose deaths in all U.S. counties, controlling for a number of socioeconomic characteristics. The results suggest that overdose deaths are associated with significant declines in self-employment rates. The coefficients on overdose death rates are generally larger in magnitude for rural counties than for larger metro counties.
\end{abstract}

Keywords: overdose; opioids; drugs; entrepreneurship determinants; self-employment; labor

JEL Classification: E61; L65; J21

\section{Introduction}

The U.S. has never faced an addiction crisis as destructive as the current opioid epidemic. The Center for Behavioral Health Statistics and Quality (2018) estimates that approximately 1.7 million Americans were addicted to prescription opioid pain relievers such as morphine, oxycodone, and hydrocodone, and approximately 650,000 were addicted to heroin or illicitly made synthetic drugs fentanyl in 2017. As a result, more Americans died from overdoses involving opioids than the total number of deaths from gun violence, HIV/AIDS, or automobile accidents. In particular, the number of overdose deaths involving opioids has increased at a staggering rate over the past two decades, from 8048 in 1999 to 47,600 in 2017 (Hedegaard et al. 2018).

Though the opioid crisis is often referred to as a "public health crisis," the social impacts of the crisis on communities extend far beyond public health. Recent works have shown opioid usage has a significant adverse impact on labor force participation (Denk 2019), and employment to population and unemployment rates (Harris et al. 2019), and the school performance of children (Cotti et al. 2019). This research aims to derive a better understanding of the toll opioids have on communities by examining the relationship between overdose deaths and self-employment rates in all U.S. counties.

Self-employment rates have been shown to be strongly related with local income and employment growth (Glaeser et al. 2015; Fleming and Goetz 2011; Henderson and Weiler 2010), as well as business creation and innovation in communities (Faggio and Silva 2012; Acs and Armington 2006). If overdose deaths are associated with lower self-employment rates, then communities struggling with opioid dependency could face additional barriers to long-term local economic development. This is especially true for rural areas which are more dependent on self-employment for job creation than urban areas (Goetz and Rupasingha 2014).

The empirical models measure how self-employment rates change in relation to overdose death rates in all U.S. counties for the period 2009 to 2017. The models control for numerous socioeconomic 
characteristics and include rural-urban classification and yearly fixed effects to control for heterogeneity in neighborhood characteristics over time.

The empirical models reveal a significant adverse relationship between overdose deaths and self-employment rates in counties. The results imply that, other factors constant, a marginal increase in the rate of overdose deaths per 100,000 residents was associated with a 0.12 percent decline in self-employment rates, and a one percent increase in overdose deaths per 100,000 residents was associated with a 1.8 percent decline in self-employment rates. The unit-coefficients on overdose death rates were largest in magnitude in rural counties, while the elasticities of overdose death rates were largest in magnitude in large metro population counties.

The rest of this paper proceeds as follows. Section 2 briefly reviews relevant literature on drug dependency, determinants of self-employment, and discusses the potential ways which drug dependency may influence self-employment. Section 3 describes the data and the empirical methodology used to examine the relationship between drug overdoses and self-employment. Section 4 presents the results and Section 5 concludes.

\section{Previous Literature}

No previous research to date has examined the relationship between overdose deaths and self-employment. However, this research is related to two disparate streams of literature that have been widely researched: one on the impacts of drug overdoses to communities, and the other on the determinants of self-employment. A brief summary of each follows.

A number of previous works have estimated the social costs associated with drug overdoses, primarily opioid overdoses, which accounted for accounted for $75 \%$ of all drug related overdoses in 2017 (Hedegaard et al. 2018). The social costs of opioid dependency include their impact on healthcare costs, premature mortality, social services, education, and criminal justice, and the implicit costs in terms of lost productivity, employment, and tax revenue. Florence et al. (2016) estimates that the total costs of abused legally prescribed opioids were equal to $\$ 78.5$ billion in 2013 , an estimate which included additional healthcare costs, foregone earnings, addiction treatment, and criminal justice costs. When including the costs of premature fatality in addition to non-fatality costs, the U.S. Council of Economic Advisers (2017) estimated the total cost of the opioid crisis as $\$ 504$ billion. Most recently, Davenport et al. (2019) estimated that the total economic burden of non-medical usage only, from 2015 to 2019 , was at least $\$ 631$ billion, which amounts to more than 3\% of total U.S. Gross Domestic Product.

The prevalence of opioid usage has been shown to be strongly related to economic conditions in the surrounding community. Hollingsworth et al. (2017) found that opioid death rates rise by 3.6 percent for every percentage point increase in unemployment in the surrounding county. Similarly, Carpenter et al. (2017) found that economic downturns at the state level were associated with statistically significant increases in the use of prescription opioids such as Percocet and Vicodin. Case and Deaton (2017) found that mortality and morbidity, particularly due to drugs and alcohol, have been increasing at a higher rate among white working-class adults without a college degree than for other groups, which is related to the decline in labor market opportunities and the increasing availability of opioids.

Given the social costs of the opioid crisis and its relationship with adverse economic conditions, it would be reasonable to presume that higher opioid usage is associated with lower rates of entrepreneurship in entrepreneurship. However, previous research has shown that some components of drug activities can have positive impacts on self-employment. For example, Fairlie (2002) found that individuals engaged in drug dealing as youth were significantly more likely to become self-employed as adults. Fairlie posits that drug dealing serves as a proxy for low risk aversion, entrepreneurial ability, and preferences for autonomy, which other research has shown to be positively associated with self-employment (e.g., Rees and Shah 1986; Blanchflower and Oswald 1998; Ahn 2010). In addition, previous literature has shown that higher unemployment can lead to increased entrepreneurship, which has been termed the "refugee" effect (Audretsch et al. 2001; Halicioglu and Yolac 2015). As much 
as opioid usage can lead to unemployment and diminish legal employment opportunities of users, areas with a higher prevalence of opioid usage could experience higher rates of self-employment.

Some components of drug activity, particularly drug dealing activities, are associated with the positive impacts of self-employment, and there are several reasons communities with higher rates of drug dependency would have lower rates of self-employment. Previous research has shown that self-employment and other measures of entrepreneurship such as the formation of new businesses are positively associated higher growth rates (Chatterji et al. 2014; Acs and Armington 2006; Blanchflower 2000), more college graduates (Berry and Glaeser 2005; Blanchflower 2000), higher levels of diversity and tolerance (Qian 2013; Audretsch et al. 2010), lower shares of manufacturing employment (Glaeser et al. 2015), and greater access to financial capital and self-employment income (Goetz and Rupasingha 2014; Bates and Robb 2013). Drug prevalence, particularly opioid prevalence, is associated with an adverse effect to each of these characteristics in communities.

The current research primarily contributes to the literature in two ways. First, it is the only research to empirically examine the relationship between drug overdose rates and entrepreneurship in communities. Second, it is the only work to examine the potential impacts of drug overdoses to communities using data from all U.S. counties.

\section{Data and Model}

Tables 1 and 2 present summary statistics for the key variables in the analysis. Table 1 shows mean estimated overdose death rates per 100,000 residents for all U.S. counties for the years 2009 to 2017. The data are from the National Center for Health Statistics, Centers for Disease Control and Prevention. Of note, U.S. counties have experienced substantial increases in mean overdose death rates in every year from 2009 through 2017. Overdose death rates increased by $65 \%$ during the sample period, from 12.8 to 21.1 per 100,000 residents during the same period.

Table 1. Overdose death rate per 100,000 all U.S. counties $(\mathrm{N}=3135)$.

\begin{tabular}{ccccc}
\hline Year & Mean Overdose Death Rates per 100,000 & Std. Dev. & Minimum & Maximum \\
\hline 2009 & 12.8 & 4.6 & 3.3 & 48.8 \\
2010 & 13.3 & 5.4 & 3.1 & 72.0 \\
2011 & 14.2 & 5.9 & 3.4 & 84.8 \\
2012 & 14.0 & 5.4 & 3.2 & 66.2 \\
2013 & 14.7 & 5.5 & 4.4 & 69.3 \\
2014 & 15.5 & 6.0 & 3.4 & 69.0 \\
2015 & 17.0 & 6.7 & 4.0 & 92.2 \\
2016 & 19.6 & 7.9 & 4.2 & 87.2 \\
2017 & 21.1 & 8.9 & 4.4 & 130.2 \\
\hline
\end{tabular}

Unsurprisingly, both the mean overdose death rates per 100,000 and the disparity in overdose deaths across counties increased during the sample period. In particular, the standard deviation in drug overdose deaths increased from 3.3 to 4.4 between 2009 and 2017.

The wide disparity in drug overdose death rates across the U.S. is illustrated in Figure 1 below, which shows the overdose death rates for all U.S. states in 2017. Historically manufacturing-based states in the Northeast and Mid-North Central region generally have higher rates of overdose deaths than states in other regions. The South, as well as Florida, Louisiana, and the Sun Belt states also have relatively high overdose death rates, while Texas, the Dakotas, and Nebraska have the lowest rates. 


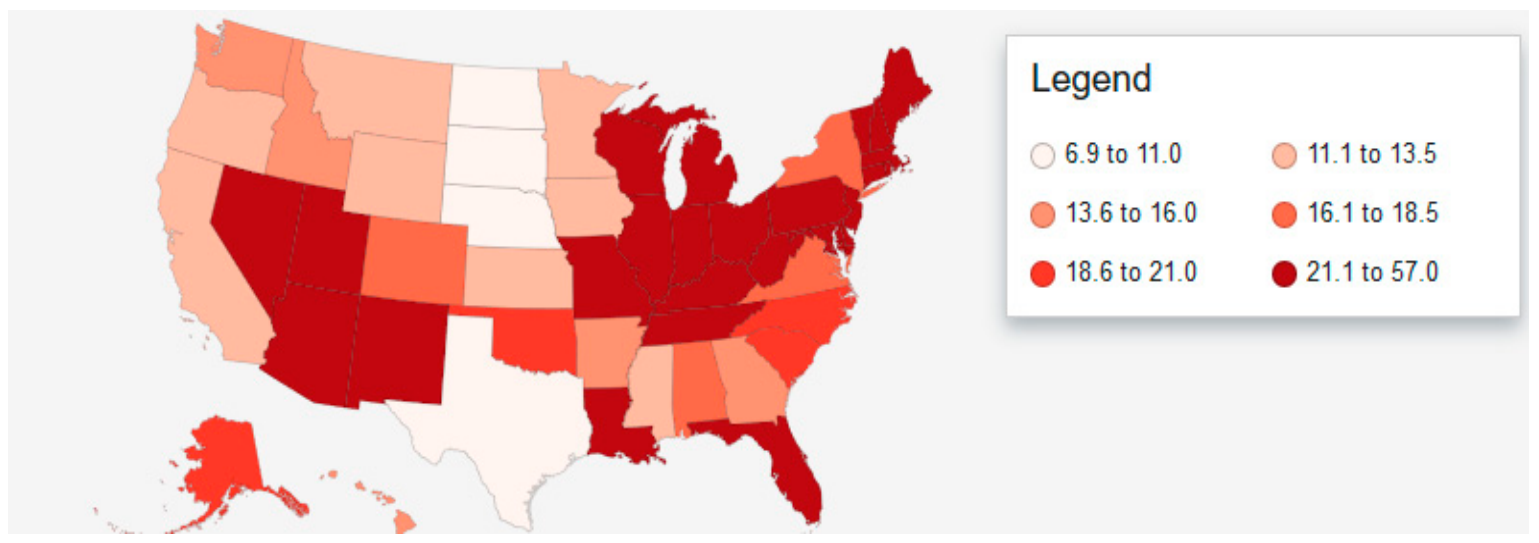

Figure 1. Rate of drug overdose deaths per 100,000 residents by state, 2017. Source: Centers for Disease Control and Prevention (2018).

Table 2 shows the trend in self-employment rates over the sample period. The percentage of self-employed people has steadily declined from $14.6 \%$ to $12.3 \%$ from 2009 to 2017 . Previous research has shown that self-employment tends to be countercyclical to the business cycle (Parker 2018; Parker et al. 2012; Faria et al. 2009). Considering the sample period begins at the end of the financial crisis and was followed by a decade of robust economic and employment growth, the decline in self-employment is not surprising. How much, if any, of the change in self-employment is attributable to the opioid crisis cannot be determined.

Table 2. Percent self-employed all U.S. counties $(\mathrm{N}=3135)$.

\begin{tabular}{ccccc}
\hline Year & Mean Percent Self-Employed & Std. Dev. & Minimum & Maximum \\
\hline 2009 & 14.6 & 6.1 & 0.0 & 56.7 \\
2010 & 14.2 & 6.2 & 0.0 & 52.4 \\
2011 & 13.8 & 6.0 & 1.4 & 52.0 \\
2012 & 13.3 & 5.8 & 1.2 & 50.0 \\
2013 & 13.0 & 5.7 & 0.0 & 47.2 \\
2014 & 12.7 & 5.6 & 0.0 & 48.8 \\
2015 & 12.5 & 5.4 & 0.0 & 46.1 \\
2016 & 12.3 & 5.3 & 0.0 & 44.8 \\
2017 & 12.3 & 5.3 & 0.0 & 46.5 \\
\hline
\end{tabular}

The main objective of the empirical models is to identify the relationship between overdose death rates and the percent of self-employed workers in counties. To do so, the related empirical models take the form of the following equation:

$$
\text { SELFEMPLOYMENTct }=\alpha 0+\alpha 1 \text { OVERDOSEct }+\alpha 2 \text { Xct }+\alpha 3 Z c+\lambda t+\varepsilon z c t
$$

where SELFEMPLOYMENTct is the self-employed percent in county $\mathrm{c}$ in year $\mathrm{t}$, OVERDOSEct refers to the rate of overdose deaths per 100,000 residents in county c in year $t$, the vector Xct represents any variable that changes across both time and counties such as unemployment, population density, and self-employment income, the vector $Z c$ represents any variable that changes only across counties such as the percent who voted for the Republican candidate in the most recent Presidential election, or the percentage of residents without health insurance. The vector $\lambda$ qt represents a time fixed effect unique to year $t$. The error term ezcqt is assumed to be idiosyncratic and randomly distributed. To address potential bias associated with serial correlation across counties, the standard errors are clustered at the county level.

The county-level characteristics include the percentage of the population aged 16 and above that is employed, the population density, poverty rate, per capita income, total self-employed income, 
percentage nonwhite residents, percentage of voters who voted for the Republican candidate in the most recent Presidential election, the percentage of residents without health insurance, percentage of residents under age 17, percentage of residents with a bachelor's degree or above, and the rural-urban classification. ${ }^{1}$ The complete list of variables and summary statistics are provided in Table 3.

Table 3. Variable definitions and summary statistics.

\begin{tabular}{|c|c|c|c|}
\hline Variable & Definition & Mean & Std. Dev. \\
\hline$\%$ Self-Employed & $\begin{array}{l}\text { Percentage of all employed workers who are } \\
\text { self-employed }\end{array}$ & 13.2 & 5.8 \\
\hline Overdose Death Rate & Number of overdose deaths involving opioids per 100,000 & 15.8 & 6.9 \\
\hline \% Employed & $\begin{array}{l}\text { Percentage of all employed workers who are } \\
\text { self-employed }\end{array}$ & 54.9 & 8.3 \\
\hline Population Density & Population per square mile & 266.9 & 1787.8 \\
\hline Poverty Rate & $\begin{array}{l}\text { Percentage of all households with income below } \\
\text { poverty line }\end{array}$ & 11.4 & 5.7 \\
\hline Per Capita Income & Per capita income $(2009 \$)$ & 32.7 & 7.9 \\
\hline Self Employed Income & Total income of self-employed workers $(\$ 1000,000$ s) & 142.3 & 557.8 \\
\hline Unemployment Rate & Unemployment rate & 7.8 & 3.6 \\
\hline$\%$ Republican Vote & $\begin{array}{l}\text { Percentage of voters who voted for Republican candidate } \\
\text { in last presidential election }\end{array}$ & 59.5 & 14.9 \\
\hline \% Under 17 & Percentage of population age 16 or under & 20.8 & 3.3 \\
\hline$\%$ Uninsured & Percentage of population without health insurance in 2008 & 17.9 & 5.9 \\
\hline$\%$ Nonwhite & $\begin{array}{l}\text { Percentage of county residents who do not identify as } \\
\text { Caucasian }\end{array}$ & 16.1 & 16.5 \\
\hline \% Higher Ed & $\begin{array}{l}\text { Percentage of county residents with a bachelor's degree } \\
\text { or higher }\end{array}$ & 18.7 & 8.5 \\
\hline Large Metro & $\begin{array}{l}=1 \text { if metro area and county have a population of } 1 \text { million } \\
\text { or more. }\end{array}$ & 0.02 & 0.14 \\
\hline Metro Fringe & $\begin{array}{c}=1 \text { if metro area has population of } 1 \text { million or more but } \\
\text { county population is less than } 1 \text { million }\end{array}$ & 0.08 & 0.27 \\
\hline Med Metro & $\begin{array}{l}=1 \text { if county is in metro area with population between } \\
\qquad 250,000 \text { to } 999,999\end{array}$ & 0.10 & 0.30 \\
\hline Micropolitan & $\begin{array}{l}=1 \text { if county has population between } 10,000 \text { to } 50,000 \text { or } \\
\text { county is adjacent to metro area of with population less } \\
\text { than } 1 \text { million }\end{array}$ & 0.15 & 0.36 \\
\hline Small Metro & $\begin{array}{l}=1 \text { county is in metro area with population between } 50,000 \\
\text { to } 249,999\end{array}$ & 0.06 & 0.25 \\
\hline Rural & $\begin{array}{l}=1 \text { if county population is less than } 49,999 \text { and is not } \\
\text { adjacent to metro area, or county population is less than } \\
19,999 \text { and is adjacent to metro area }\end{array}$ & 0.58 & 0.49 \\
\hline
\end{tabular}

\section{Results}

The results of the empirical equations for all U.S. counties are shown in Table 4. The coefficients in Specification 1 represent how county self-employment rates changed relative to a marginal increase in the value of each variable. The variables in Specification 2 are equivalent, but include logged

1 Data on self-employed income are from the Bureau of Economic Analysis. Voting data come from the MIT election lab (https://electionlab.mit.edu/data). All other socioeconomic data are from the Census Bureau's American Community Survey. 
values for overdose deaths, population, per-capita income, and self-employment. Specification 3 includes a two-year lagged value on the key variable of interest, overdose death rates. The measures of overdose death rates exhibit negative and statistically significant coefficients in all specifications, suggesting that counties with higher levels of drug overdoses exhibit lower rates of self-employment, other factors constant. In particular, an additional overdose death per 100,000 residents was associated with a 0.12 percent decrease in self-employment, while a one percent increase in overdose deaths per 100,000 residents was associated with a 1.83 percent decrease in self-employment. The coefficient on the lagged value of overdose deaths per 100,000 residents in Specification 3 is -1.91, which may suggest that counties do not feel the full impacts of overdose deaths until years after they occur.

Table 4. Estimation results, all U.S. counties $(\mathrm{N}=3082)$. Dependent variable = percent self-employed.

\begin{tabular}{|c|c|c|c|c|c|c|c|c|}
\hline Specification 1 & Coefficient & Std. Error & Specification 2 & Coefficient & Std. Error & Specification 3 & Coefficient & Std. Error \\
\hline $\begin{array}{c}\text { Overdose Death } \\
\text { Rate }\end{array}$ & $-0.12 * * *$ & 0.01 & $\begin{array}{l}\text { Log Overdose } \\
\text { Death Rate }\end{array}$ & $-1.83^{* * *}$ & 0.18 & $\begin{array}{l}\text { Log Overdose } \\
\text { Death Rate }_{(t-2)}\end{array}$ & $-1.91^{* * *}$ & 0.18 \\
\hline Pop Density & $-0.0001 * *$ & 0.00003 & Log Pop Density & $-2.12^{* * *}$ & 0.09 & Log Pop Density & $-2.12^{* * *}$ & 0.09 \\
\hline Poverty Rate & $0.10^{* * *}$ & 0.02 & Poverty Rate & $0.07^{* * *}$ & 0.02 & Poverty Rate & $0.07^{* * *}$ & 0.02 \\
\hline Self Emp Income & 0.0001 & 0.00001 & $\begin{array}{l}\text { Log Self Emp } \\
\text { Income }\end{array}$ & $1.07^{* * *}$ & 0.09 & $\begin{array}{l}\text { Log Self Emp } \\
\text { Income }\end{array}$ & $1.07^{* * *}$ & 0.09 \\
\hline Unemp Rate & $-0.21^{* * *}$ & 0.03 & Unemp Rate & $-0.11^{* * *}$ & 0.03 & Unemp Rate & $-0.11^{* * *}$ & 0.03 \\
\hline$\%$ Repub Vote & $0.02 * *$ & 0.01 & $\%$ Repub Vote & $0.01 * *$ & 0.01 & $\%$ Repub Vote & $0.01 * *$ & 0.01 \\
\hline \% Under 17 & $-0.29^{* * *}$ & 0.04 & \% Under 17 & $-0.23^{* * *}$ & .03 & \% Under 17 & $-0.23^{* * *}$ & .03 \\
\hline$\%$ Higher Ed & 0.02 & 0.01 & $\%$ Higher Ed & $0.04 * * *$ & 0.01 & $\%$ Higher Ed & $0.04 * * *$ & 0.01 \\
\hline Large Metro & $-4.44^{* * *}$ & 0.40 & Large Metro & 0.87 & 0.51 & Large Metro & 0.87 & 0.51 \\
\hline Large Fringe & $-4.56^{* * *}$ & 0.26 & Large Fringe & $-1.11^{* * *}$ & 0.28 & Large Fringe & $-1.11^{* * *}$ & 0.28 \\
\hline Med Metro & $-4.25^{* * *}$ & 0.19 & Med Metro & $-1.57^{* * *}$ & 0.22 & Med Metro & $-1.57^{* * *}$ & 0.22 \\
\hline Micropolitan & $-3.26^{* * *}$ & 0.17 & Micropolitan & $-2.16^{* * *}$ & 0.16 & Micropolitan & $-2.16^{* * *}$ & 0.16 \\
\hline Small Metro & $-4.54^{* * *}$ & 0.25 & Small Metro & $-2.40 * * *$ & 0.26 & Small Metro & $-2.40^{* * *}$ & 0.26 \\
\hline QIC & 27,790 & & QIC & 27,812 & & QIC & 27,812 & \\
\hline
\end{tabular}

Standard errors clustered at the county level. Year fixed effects included. ${ }^{* * *} p<0.01,{ }^{* *} p<0.05,{ }^{*} p<0.10$.

The coefficients on most other variables exhibit the expected signs. Self-employment was positively associated with the percentage of employed workers, the percentage of highly educated workers, per-capita income, and self-employed income levels, which suggests that residents are more likely to become employed in areas with higher returns to entrepreneurship. The percentage of residents without health insurance and poverty rates both take on unexpected positive coefficients. The percentage of voters who voted for a Republican candidate in the most recent Presidential election, which is a proxy for the counties' political climate, also takes on a positive coefficient. The coefficients on population density, the percentage of the population under age 17, and the percentage of nonwhite resident also take on negative and significant coefficients. Counter to the "refugee" effect hypothesis, the coefficients on unemployment rates are negative and significant.

The coefficients on the rural-urban classification, for which rural counties are the benchmark, suggest that all metro counties have significantly lower rates of self-employment compared to rural counties, a result which was also found by Goetz and Rupasingha (2014). The coefficients suggest small metro counties, which are those in a metro area with population between 50,000 to 249,999, have lowest rates of self-employment, other factors constant. 
Tables 5 and 6 show how the results vary according to county rural-urban classifications. Table 5 shows the coefficients on the absolute values of each variable, while Table 6 shows the coefficients on logged values of overdose death rates, population density, per capita income, and self-employed income. The results on overdose death rates are negative and statistically significant for all rural-urban classifications except small metro counties, and the coefficient on overdose death rates are largest in magnitude in rural counties. The coefficients in Table 5 suggest that a marginal increase in the overdose death rate was associated with a 0.18 percent decline in the rate of self-employment in rural counties, while the coefficient on the logged value in overdose death rate in Table 6 suggests a one percent increase in overdose death rates was associated with 2.74 percent decrease in self-employment. The second largest coefficients on overdose death rates are in metro fringe counties, but the magnitude of the coefficients is less than half the magnitude of the coefficients of rural counties.

Table 5. Estimation results by urban-rural classification-Specification 1. Dependent variable = percent self-employed.

\begin{tabular}{|c|c|c|c|c|c|c|}
\hline \multirow[b]{2}{*}{ Variable } & \multicolumn{2}{|c|}{ Rural Only (N = 1818) } & \multicolumn{2}{|c|}{ Large Metro $(N=63)$} & \multicolumn{2}{|c|}{ Metro Fringe $(N=248)$} \\
\hline & Coefficient & Std. Error & Coefficient & Std. Error & Coefficient & Std. Error \\
\hline Overdose Death Rate & $-0.180^{* * *}$ & 0.016 & -0.007 & 0.010 & $-0.085^{* * *}$ & 0.013 \\
\hline \% Employed & $0.313 * * *$ & 0.024 & 0.048 & 0.051 & $0.170 * * *$ & 0.039 \\
\hline Population Density & -0.002 & 0.002 & $-0.0002 *$ & 0.0001 & $-0.001^{* * *}$ & 0.0002 \\
\hline Poverty Rate & $0.145^{* * *}$ & 0.029 & $-0.212 * *$ & 0.068 & 0.082 & 0.055 \\
\hline Per Capita Income & $0.053 *$ & 0.031 & -0.029 & 0.028 & $0.114^{* * *}$ & 0.031 \\
\hline Self Employed Income & $-0.014^{* * *}$ & 0.003 & $0.0003^{* * *}$ & 0.0001 & 0.0005 & 0.0003 \\
\hline Unemployment Rate & $-0.292^{* * *}$ & 0.032 & 0.185 & 0.106 & -0.122 & 0.154 \\
\hline \% Republican Vote & $0.034^{* * *}$ & 0.009 & -0.023 & 0.026 & -0.040 & 0.025 \\
\hline \% Under 17 & $-0.291^{* * *}$ & 0.054 & 0.143 & 0.125 & -0.089 & 0.071 \\
\hline$\%$ Uninsured & $0.110 * * *$ & 0.024 & $0.140^{* * *}$ & 0.033 & $0.261 * * *$ & 0.056 \\
\hline$\%$ Nonwhite & $-0.062^{* * *}$ & 0.009 & -0.031 & 0.020 & $-0.088^{* * *}$ & 0.019 \\
\hline$\%$ Higher Ed & $0.132 * * *$ & 0.029 & $0.166^{* * *}$ & 0.046 & 0.009 & 0.045 \\
\hline \multirow[t]{2}{*}{ QIC } & 27,790 & & 711 & & 2391 & \\
\hline & \multicolumn{2}{|c|}{ Medium Metro (N = 312) } & \multicolumn{2}{|c|}{ Micropolitan $(\mathrm{N}=483)$} & \multicolumn{2}{|c|}{ Small Metro $(\mathrm{N}=282)$} \\
\hline Variable & Coefficient & Std. Error & Coefficient & Std. Error & Coefficient & Std. Error \\
\hline Overdose Death Rate & $-0.050^{* * *}$ & 0.011 & $-0.061^{* * *}$ & 0.015 & -0.004 & 0.025 \\
\hline \% Employed & $0.106^{* * *}$ & 0.024 & $0.182 * * *$ & 0.030 & $0.219^{* * *}$ & 0.046 \\
\hline Population Density & -0.0002 & 0.0003 & $-0.011^{* * *}$ & 0.003 & $-0.003 * *$ & 0.001 \\
\hline Poverty Rate & -0.013 & 0.038 & -0.013 & 0.042 & $-0.382^{* * *}$ & 0.082 \\
\hline Per Capita Income & -0.018 & 0.024 & $0.007^{* * *}$ & 0.030 & -0.028 & 0.039 \\
\hline Self Employed Income & $0.001 *$ & 0.0005 & $0.012^{* * *}$ & 0.003 & 0.001 & 0.002 \\
\hline Unemployment Rate & -0.019 & 0.051 & $0.170 *$ & 0.089 & 0.059 & 0.066 \\
\hline \% Republican Vote & $0.022 *$ & 0.011 & 0.001 & 0.011 & $-0.029 *$ & 0.017 \\
\hline \% Under 17 & 0.3774 & 0.5910 & -0.072 & 0.065 & -0.033 & 0.123 \\
\hline$\%$ Uninsured & $0.148^{* * *}$ & 0.035 & $0.090^{* * *}$ & 0.031 & $0.290 * * *$ & 0.059 \\
\hline$\%$ Nonwhite & $-0.063^{* * *}$ & 0.014 & $-0.041^{* * *}$ & 0.013 & -0.017 & 0.020 \\
\hline \% Higher Ed & $0.101 * * *$ & 0.022 & $0.067^{* * *}$ & 0.025 & 0.024 & 0.031 \\
\hline QIC & 3071 & & 4569 & & 1964 & \\
\hline
\end{tabular}

Standard errors clustered at the county level. Year fixed effects included. ${ }^{* * *} p<0.01,{ }^{* *} p<0.05,{ }^{*} p<0.10$. 
Table 6. Estimation results by urban-rural classification-Specification 2. Dependent variable = percent self-employed.

\begin{tabular}{|c|c|c|c|c|c|c|}
\hline \multirow[b]{2}{*}{ Variable } & \multicolumn{2}{|c|}{ Rural Only (N = 1818) } & \multicolumn{2}{|c|}{ Large Metro $(N=63)$} & \multicolumn{2}{|c|}{ Metro Fringe $(\mathrm{N}=248)$} \\
\hline & Coefficient & Std. Error & Coefficient & Std. Error & Coefficient & Std. Error \\
\hline Log Overdose Death Rate & $-2.735^{* * *}$ & 0.313 & $-0.682 * *$ & 0.323 & $-1.048^{* * *}$ & 0.266 \\
\hline \% Employed & $0.219^{* * *}$ & 0.023 & -0.009 & 0.060 & 0.061 & 0.040 \\
\hline Log Population Density & $-2.457^{* * *}$ & 0.115 & $-0.338^{*}$ & 0.175 & $-1.486^{* * *}$ & 0.189 \\
\hline Poverty Rate & $0.110 * * *$ & 0.025 & $-0.162 * *$ & 0.069 & -0.061 & 0.051 \\
\hline Log Per Capita Income & $1.614^{* * *}$ & 0.165 & $0.992 * *$ & 0.451 & $1.601 * * *$ & 0.331 \\
\hline $\begin{array}{l}\text { Log Self Employed } \\
\text { Income }\end{array}$ & $1.297 * * *$ & 0.141 & $0.653^{* *}$ & 0.257 & $0.394^{* *}$ & 0.185 \\
\hline Unemployment Rate & $-0.144^{* * *}$ & 0.031 & -0.081 & 0.119 & -0.161 & 0.179 \\
\hline \% Republican Vote & $0.029^{* * *}$ & 0.009 & $-0.054 *$ & 0.030 & $-0.054 *$ & 0.028 \\
\hline \% Under 17 & $-0.232 * * *$ & 0.045 & 0.039 & 0.127 & -0.004 & 0.067 \\
\hline$\%$ Uninsured & -0.031 & 0.022 & $0.136^{* *}$ & 0.038 & $0.222 * * *$ & 0.052 \\
\hline$\%$ Nonwhite & $-0.059^{* * *}$ & 0.009 & -0.025 & 0.023 & $-0.069 * * *$ & 0.019 \\
\hline \% Higher Ed & 0.034 & 0.025 & 0.068 & 0.048 & $0.083 * *$ & 0.036 \\
\hline \multirow[t]{2}{*}{ QIC } & 16,189 & & 2734 & & 2872 & \\
\hline & \multicolumn{2}{|c|}{ Medium Metro $(\mathrm{N}=312)$} & \multicolumn{2}{|c|}{ Micropolitan $(\mathrm{N}=483)$} & \multicolumn{2}{|c|}{ Small Metro $(\mathrm{N}=282)$} \\
\hline Variable & Coefficient & Std. Error & Coefficient & Std. Error & Coefficient & Std. Error \\
\hline Log Overdose Death Rate & $-0.709 * *$ & 0.308 & $-1.209^{* * *}$ & 0.347 & 0.036 & 0.461 \\
\hline \% Employed & $0.118^{* * *}$ & 0.035 & $0.169^{* * *}$ & 0.039 & $0.197 * * *$ & 0.049 \\
\hline Log Population Density & $-0.758^{* * *}$ & 0.155 & $-1.526^{* * *}$ & 0.216 & $-1.451^{* * *}$ & 0.291 \\
\hline Poverty Rate & 0.011 & 0.043 & -0.005 & 0.044 & $-0.326^{* * *}$ & 0.070 \\
\hline Log Per Capita Income & 0.262 & 0.253 & $0.592 * *$ & 0.292 & 0.549 & 0.436 \\
\hline $\begin{array}{l}\text { Log Self Employed } \\
\text { Income }\end{array}$ & $0.287^{*}$ & 0.157 & $0.906^{* * *}$ & 0.223 & -0.180 & 0.312 \\
\hline Unemployment Rate & 0.010 & 0.075 & $0.211^{* *}$ & 0.096 & 0.151 & 0.101 \\
\hline \% Republican Vote & 0.012 & 0.012 & 0.008 & 0.012 & $-0.027 *$ & 0.015 \\
\hline \% Under 17 & 0.036 & 0.056 & $-0.101 *$ & 0.060 & -0.033 & 0.106 \\
\hline$\%$ Uninsured & $0.126^{* * *}$ & 0.035 & 0.050 & 0.032 & $0.271^{* * *}$ & 0.047 \\
\hline$\%$ Nonwhite & $-0.057^{* * *}$ & 0.014 & $-0.040^{* * *}$ & 0.014 & -0.018 & 0.017 \\
\hline \% Higher Ed & $0.112^{* * *}$ & 0.025 & $0.069^{* * *}$ & 0.026 & $0.071^{* *}$ & 0.031 \\
\hline QIC & 2978 & & 4456 & & 1906 & \\
\hline
\end{tabular}

Standard errors clustered at the county level. Year fixed effects included. ${ }^{* * *} p<0.01,{ }^{* *} p<0.05,{ }^{*} p<0.10$.

Turning our attention to the coefficients of other explanatory variables, Table 6 shows that total annual self-employed income in the county takes on positive and significant coefficients for all county classifications, and they were largest in magnitude for rural and micropolitan counties, perhaps suggesting that potential returns to self-employment play a bigger role in the choice of self-employment in smaller population areas, which are likely to have relatively fewer highly compensated salary or wage opportunities. The coefficient on population density is negative and significant in all classifications but is largest in magnitude in rural counties. This result is in contrast to the results found by Goetz and Rupasingha (2014), which suggested that population density captured the presence of agglomeration economies. Higher poverty rates were associated with higher rates of self-employment in rural and small metro counties, which may reflect a lack of wage or salary positions available to low-income residents in rural or smaller metro areas. More Republican rural counties were associated with higher rates of self-employment, but more Republican large metro and metro fringe counties were associated with lower rates of self-employment. Finally, the percentage of youth in the county had a negative and significant relationship with self-employment in rural counties, but the coefficient of youth was not statistically significant in any metro classification. 


\section{Conclusions}

Over the past two decades, the opioid crisis has devastated millions of families and thousands of communities across the U.S., yet few academic studies to date have attempted to measure the potential economic impacts that the opioid crisis has had on communities. This study aims to partially fill this void by estimating the relationship that drug overdose deaths have with one important measure of economic development and entrepreneurship: self-employment.

The main findings are that the percentage of self-employed workers is significantly lower in counties with higher rates of drugs overdose deaths, other factors constant. The magnitude of the coefficients on the overdose death rate is highest in rural and lower population counties. Self-employment income and population density also play an important role in self-employment rates, particularly in rural counties.

To the extent that self-employment has positive impacts on local economic development, innovation, and employment growth (e.g., Fleming and Goetz 2011; Henderson and Weiler 2010), the potential negative impact that drug overdoses have on self-employment represents another economic cost of the opioid crisis to communities, one that to date has not been estimated by researchers or considered by policymakers.

Though this paper provides clear evidence of the negative association between drug overdose deaths and self-employment rates, the empirical models cannot infer the direction of causality between drug overdose deaths and self-employment, nor can this research identify the mechanism by which drug overdose deaths may impact self-employment rates. Whether the relationship is driven by drug overdose deaths specifically or by general drug usage, for which overdose deaths serve as a proxy, is an important policy question for future research. In addition, whether other measures of entrepreneurship, such as new proprietorships, or measures of innovation such as new patent formation, are related to drug overdose deaths is left for future researchers to consider.

Funding: This research received no external funding.

Conflicts of Interest: The authors declare no conflict of interest.

\section{References}

Acs, Zoltan J., and Catherine Armington. 2006. Entrepreneurship, Geography, and American Economic Growth. Cambridge: Cambridge University Press.

Ahn, Taehyun. 2010. Attitudes toward risk and self-employment of young workers. Labour Economics 17: 434-42. [CrossRef]

Audretsch, David B., Martin A. Carree, and Adriaan Roy Thurik. 2001. Does Entrepreneurship Reduce Unemployment? No. 01-074/3. Tinbergen Institute discussion paper. Amsterdam: Tinbergen Institute.

Audretsch, David, Dirk Dohse, and Annekatrin Niebuhr. 2010. Cultural diversity and entrepreneurship: A regional analysis for Germany. The Annals of Regional Science 45: 55-85. [CrossRef]

Bates, Timothy, and Alicia Robb. 2013. Greater access to capital is needed to unleash the local economic development potential of minority-owned businesses. Economic Development Quarterly 27: 250-59. [CrossRef]

Berry, Christopher R., and Edward L. Glaeser. 2005. The divergence of human capital levels across cities. Papers in Regional Science 84: 407-44. [CrossRef]

Blanchflower, David G. 2000. Self-employment in OECD countries. Labour economics 7: 471-505. [CrossRef]

Blanchflower, David G., and Andrew J. Oswald. 1998. What makes an entrepreneur? Journal of Labor Economics 16: 26-60. [CrossRef]

Carpenter, Christopher S., Chandler B. McClellan, and Daniel I. Rees. 2017. Economic conditions, illicit drug use, and substance use disorders in the United States. Journal of Health Economics 52: 63-73. [CrossRef]

Case, Anne, and Angus Deaton. 2017. Mortality and morbidity in the 21st century. Brookings Papers on Economic Activity 1: 397-476. [CrossRef]

Center for Behavioral Health Statistics and Quality. 2018. 2017 National Survey on Drug Use and Health: Detailed Tables; Rockville: Substance Abuse and Mental Health Services Administration. 
Centers for Disease Control and Prevention. 2018. National Center for Injury Prevention and Control. Drug Overdose Deaths. Available online: https://www.cdc.gov/drugoverdose/data/statedeaths/drug-overdosedeath-2017.html (accessed on 20 August 2019).

Chatterji, Aaron, Edward Glaeser, and William Kerr. 2014. Clusters of entrepreneurship and innovation. Innovation Policy and the Economy 14: 129-66. [CrossRef]

Cotti, Chad D., John M. Gordanier, and Orgul D. Ozturk. 2019. Opioid Prescriptions and the Educational Performance of Children. Available online: http://dx.doi.org/10.2139/ssrn.3476128 (accessed on 17 September 2019).

Davenport, Stoddard, Alexandra Weaver, and Matt Caverly. 2019. Economic Impact of Non-Medical Opioid Use in the United States: Annual Estimates and Projections for 2015 through 2019. Society of Actuaries. Available online: https:/www.soa.org/globalassets/assets/files/resources/research-report/2019/econ-impactnon-medical-opioid-use.pdf (accessed on 25 September 2019).

Denk, Erich. 2019. The Relationship between Prime-age Male Labor Force Participation and Opiod Overdoses in Appalachia. Ph.D. dissertation, Georgetown University, Washington, DC, USA.

Faggio, Giulia, and Olmo Silva. 2012. Does Self-Employment Measure Entrepreneurship? Evidence from Great Britain. Spatial Economics Research Centre Discussion Paper 109. London: London School of Economics.

Fairlie, Robert W. 2002. Drug dealing and legitimate self-employment. Journal of Labor Economics 20: 538-37. [CrossRef]

Faria, João Ricardo, Juan Carlos Cuestas, and Luis A. Gil-Alana. 2009. Unemployment and entrepreneurship: A cyclical relation? Economics Letters 105: 318-20. [CrossRef]

Fleming, David A., and Stephan J. Goetz. 2011. Does local firm ownership matter? Economic Development Quarterly 25: 277-81. [CrossRef]

Florence, Curtis, Feijun Luo, Likang Xu, and Chao Zhou. 2016. The Economic Burden of Prescription Opioid Overdose, Abuse, and Dependence in the United States, 2013. Medical Care 54: 901-6. [CrossRef]

Glaeser, Edward L., Sari Pekkala Kerr, and William R. Kerr. 2015. Entrepreneurship and urban growth: An empirical assessment with historical mines. Review of Economics and Statistics 97: 498-520. [CrossRef]

Goetz, Stephan J., and Anil Rupasingha. 2014. The determinants of self-employment growth: Insights from county-level data, 2000-2009. Economic Development Quarterly 28: 42-60. [CrossRef]

Halicioglu, Ferda, and Sema Yolac. 2015. Testing the impact of unemployment on self-employment: Evidence from OECD countries. Procedia-Social and Behavioral Sciences 195: 10-17. [CrossRef]

Harris, Matthew C., Lawrence M. Kessler, Matthew N. Murray, and Beth Glenn. 2019. Prescription Opioids and Labor Market Pains: The Effect of Schedule II Opioids on Labor Force Participation and Unemployment. Journal of Human Resources, 1017-9093R2. [CrossRef]

Hedegaard, Holly, Margaret Warner, and Arialdi M. Miniño. 2018. Drug Overdose Deaths in the United States, 1999-2017; NCHS Data Brief, no 329; Hyattsville: National Center for Health Statistics.

Henderson, Jason, and Stephan Weiler. 2010. Entrepreneurs and job growth: probing the boundaries of time and space. Economic Development Quarterly 24: 23-32. [CrossRef]

Hollingsworth, Alex, Christopher J. Ruhm, and Kosali Simon. 2017. Macroeconomic conditions and opioid abuse. Journal of Health Economics 56: 222-33. [CrossRef]

Parker, Simon C. 2018. The Economics of Entrepreneurship. Cambridge: Cambridge University Press.

Parker, Simon C., Emilio Congregado, and Antonio A. Golpe. 2012. Is entrepreneurship a leading or lagging indicator of the business cycle? Evidence from UK self-employment data. International Small Business Journal 30: 736-53. [CrossRef]

Qian, Haifeng. 2013. Diversity versus tolerance: The social drivers of innovation and entrepreneurship in US cities. Urban Studies 50: 2718-35. [CrossRef]

Rees, Hedley, and Anup Shah. 1986. An empirical analysis of self-employment in the UK. Journal of Applied Econometrics 1: 95-108. [CrossRef]

U.S. Council of Economic Advisers. 2017. The Underestimated Cost of the Opioid Crisis; Washington: U.S. Council of Economic Advisers. 